ORIGINAL ARTICLE

\title{
Increased serum levels of interleukin 6 are associated with severe intraventricular haemorrhage in extremely premature infants
}

\author{
A Heep, D Behrendt, P Nitsch, R Fimmers, P Bartmann, J Dembinski
}

Arch Dis Child Fetal Neonatal Ed 2003;88:F501-F504

See end of article for authors' affiliations

.....................

Correspondence to: Dr Heep, Department of Neonatology, Friedrich Wilhelm University, Adenauerallee 119 D-53113 Bonn, Germany; a.heep@uni-bonn.de

Accepted

4 December 2002

\begin{abstract}
Background: Intraventricular haemorrhage (IVH) and periventricular leucomalacia (PVL) in premature infants presumably have many causes. It has been proposed that inflammatory processes in the fetomaternal unit play an important role in the pathogenesis of these lesions.

Objective: To study the correlation of postpartum serum interleukin 6 (IL6) concentration as a marker of inflammation and neonatal cerebral morbidity in preterm infants $<28$ weeks of gestational age.

Methods: A total of 88 infants were grouped according to maximum serum IL6 levels within 12 hours post partum: group $A(n=50), \leqslant 100 \mathrm{pg} / \mathrm{ml}$; group $B(\mathrm{n}=38),>100 \mathrm{pg} / \mathrm{ml}$. Ultrasound studies and clinical assessment were performed routinely.

Results: IVH was noted significantly more often in group B $(24 / 38 ; 63 \%)$ than in group A $(19 / 50 ; 38 \%)$ ( $p=0.02$ ). In a multiple logistic regression model, raised serum IL 6 independently predicted development of severe IVH (odds ratio $8.4 ; 95 \%$ confidence interval 2.85 to $24.9 ; p=0.0001$ ).

Conclusions: Raised serum IL 6 may serve as a marker for severe IVH in infants $<28$ weeks of gestational age. Although cerebral morbidity in premature infants is determined by different variables, the identification of systemic inflammation can help to define the need for anti-inflammatory strategies to prevent cerebral morbidity.
\end{abstract}

$P$ roinflammatory cytokines are a major component of systemic inflammatory response, local activation of endothelial inflammation processes, and premature birth. ${ }^{1}$ Inflammation of the fetomaternal unit may lead to chorioamnionitis and omphalovasculitis, which are regarded as definite signs of fetal involvement..$^{2-4}$ Cytokine pathways have been proposed as a possible link between systemic infection of the fetomaternal unit and consecutive neonatal brain injury. ${ }^{5-8}$

Premature infants of $<28$ weeks gestation are at highest risk of cerebral damage and developmental retardation. ${ }^{9-11}$ Vulnerability of the immature cerebral vessels is thought to be an important factor in the pathogenesis of cerebral haemorrhage. $^{10}$ Recently, more detailed analyses have demonstrated the role of inflammatory processes in this context. ${ }^{45} 8$ 12-15 There is evidence of involvement of cytokine release, with subsequent endothelial damage of the germinal matrix and the white matter. ${ }^{6}{ }^{16-19}$ An early marker of the activated inflammatory cascade is interleukin (IL) 6. ${ }^{20}{ }^{21}$ IL6 levels in serum peak 3-4 hours after endotoxin stimulation and may be used as an early diagnostic marker of neonatal bacterial infection. ${ }^{21}$

The aim of this study was to correlate early neonatal inflammatory response and development of severe intraventricular haemorrhage (IVH) and periventricular leucomalacia $(\mathrm{PVL})^{10}$ in high risk preterm infants. We hypothesised that an elevated serum IL6 concentration at 12 hours of postnatal age reflects activation of the proinflammatory cascade. Thus, IL6 may increase cerebral vascular endothelial permeability, $^{22} 23$ being part of an important pathophysiological mechanism for the development and progress of IVH.

\section{PATIENTS AND METHODS}

A retrospective cohort study was carried out on 97 inborn preterm infants, gestational age $<28$ weeks, who were admitted consecutively to a single tertiary neonatal intensive care unit at the University of Bonn between January 1999 and December 2001. Nine patients were excluded from analysis because of missing IL6 values $(n=5)$ or postnatal death within 12 hours $(\mathrm{n}=4)$. The remaining 88 infants were grouped according to maximum IL6 concentration $(<97 \text { th centile of healthy neonates })^{12} 21$ within 12 hours of postnatal age: group $\mathrm{A}, \leqslant 100 \mathrm{pg} / \mathrm{ml}$; group $\mathrm{B},>100 \mathrm{pg} / \mathrm{ml}$. Serum IL6 concentration was measured as part of routine laboratory testing (Immulite; DPC-Biermann, Bad Nauheim, Germany). Clinical and outcome data of the study population were taken from patient records. The clinical risk index for babies (CRIB score) was determined for all study infants from birth weight, gestational age, presence or absence of congenital malformations, worst base excess, and minimum and maximum appropriate fractions of inspired oxygen $\left(\mathrm{FIO}_{2}\right)$ during the first $12 \mathrm{~h}$ of life. ${ }^{24}{ }^{25}$ All patients were routinely monitored by central or peripheral arterial catheter. Arterial hypotension within the first 12 hours of life was defined as mean arterial blood pressure less than $28 \mathrm{~mm}$ $\mathrm{Hg}^{26}$ The treatment of arterial hypotension followed a standardised protocol: up to $2 \times 10 \mathrm{ml}$ saline infusion $/ \mathrm{kg}$ body weight/30 minutes, followed by catecholamine treatment (dopamine infusion $5-10 \mu \mathrm{g} / \mathrm{kg} / \mathrm{min}$ or adrenaline (epinephrine) infusion $0.1-0.3 \mu \mathrm{g} / \mathrm{kg} / \mathrm{min}$ ) to maintain blood pressure in the normal range. Cerebral ultrasound was performed with a $8.5-10 \mathrm{MHz}$ transducer (Vingmed Vivid FiVe) at $0-2,12,24,36,72$ hours after birth and at days 7 and 28 of postnatal age. The sonographic findings of IVH and PVL were classified using the criteria given by Volpe ${ }^{10}{ }^{27}:(a)$ grade 1 (mild), germinal matrix haemorrhage with no or minimal IVH; (b) grade 2 (moderate; $10-50 \%$ of ventricular area in

Abbreviations: IL, interleukin; IVH, intraventricular haemorrhage; PVL, periventricular leucomalacia 
parasagittal scan); (c) grade 3 ( severe; $>50 \%$ of ventricular area in parasagittal scan); (d) apparent periventricular haemorrhagic infarction. According to the classification given by Volpe, in our study severe IVH was defined as either grade 3 IVH or IVH with apparent periventricular haemorrhagic infarction.

Death before postnatal day 28 postnatal and/or severe IVH was defined as a secondary outcome variable.

\section{DATA ANALYSIS}

For statistical analysis, we used the Mann-Whitney U test and $\chi^{2}$ test with two sided $\mathrm{p}$ values to compare values between groups of patients. The effect of serum IL6 $\geqslant 100 \mathrm{pg} / \mathrm{ml}$ at 12 hours of postnatal age and potential confounding variables (gestational age, birth weight, cord blood $\mathrm{pH}$, antenatal steroid exposure, catecholamine treatment, serum $\mathrm{C}$ reactive protein concentration, blood leucocyte count) on the incidence of total IVH or severe IVH was tested by stepwise logistic multivariate regression analysis. Data were processed by use of statistical software SPSS 10.7 (SPSS Inc, Chicago, Illinois, USA).

\section{RESULTS}

Table 1 summarises the perinatal data of infants in groups A and B. The two groups were similar with respect to gestational age, sex, birth weight, antenatal steroid exposure, arterial umbilical $\mathrm{pH}$, and CRIB score. The variables serum $\mathrm{C}$ reactive protein concentration $(p=0.012)$ and catecholamine treatment $(p=0.002)$ measured at 12 hours of postnatal age were different in the two groups.

In infants with elevated IL6 concentrations (group B), a higher incidence of IVH was noted $(p=0.021)$. Severe IVH also occurred more often in group $B(p=0.0001)$. There was a tendency towards a higher rate of survival at day 28 in group A ( $88 \%$ v.68\%; p $=0.077)$. Infants with raised IL6 had a higher risk of death at $<28$ days of postnatal age or survival with severe IVH at 28 days of postnatal age $(\mathrm{p}=0.0001)$ than infants with IL6 $\leqslant 100 \mathrm{pg} / \mathrm{ml}$ (group A) (table 2).

In the study population, IVH (43/88) correlated with the variables gestational age $(p=0.003)$, IL6 $>100 \mathrm{pg} / \mathrm{ml}$ $(\mathrm{p}=0.034)$, and catecholamine treatment $(\mathrm{p}=0.002)$ (table 3 ). Birth weight, $C$ reactive protein $>5 \mathrm{mg} / \mathrm{l}$, cord blood $\mathrm{pH}$, and leucocyte count did not correlate with IVH.

Table 1 Perinatal data of 88 infants of $<28$ weeks gestation

\begin{tabular}{llll}
\hline Characteristic & $\begin{array}{l}\text { Group A } \\
\text { (n = 50) }\end{array}$ & $\begin{array}{l}\text { Group B } \\
\text { (n = 38) }\end{array}$ & p Value \\
\hline Gestational age (weeks) & $\begin{array}{l}26+0 \\
(23+2-27+6)^{*}\end{array}$ & $\begin{array}{l}25+1 \\
(23+2-27+2)^{*}\end{array}$ & 0.09 \\
Birth weight (g) & $652(333-1000)^{*}$ & $705(470-910)^{*}$ & 0.18 \\
Male/female & $25 / 25$ & $18 / 20$ & 1.0 \\
Antenatal steroids & $47(94 \%)$ & $35(92 \%)$ & 0.43 \\
Cord blood pH & $7.32(6.9-$ & $7.32(7.13-$ & \\
& $7.46)^{*}$ & $7.44)^{*}$ & 0.62 \\
CRIB score & $8(1-21)$ & $8(1-20)$ & 0.063 \\
Catecholamine treatment & $31(62 \%)$ & $35(92 \%)$ & 0.002 \\
C reactive protein & $7(14 \%)$ & $15(39 \%)$ & 0.012 \\
>5 mg/l & & $1000(114-$ & 0.0001 \\
IL6 concentration (pg/ml) & $12(0-96)^{*}$ & $50000)^{*}$ & \\
& & $32(84 \%)$ & 0.22 \\
PDA & $34(68 \%)$ & $38(100 \%)$ & 0.25 \\
Mechanical ventilation & $48(96 \%)$ & & \\
\hline
\end{tabular}

Study population divided into two groups according to serum IL6 level at 12 hours of postnatal age: $A, \leqslant 100 \mathrm{pg} / \mathrm{ml} ; B_{1}>100 \mathrm{pg} / \mathrm{ml}$. *Values are given as median and range.

IL, interleukin; CRIB, clinical risk index for babies; PDA, patent ductus arteriosus.
Table 2 Outcome data of 88 infants of $<28$ weeks gestation

\begin{tabular}{llll}
\hline Characteristic & $\begin{array}{l}\text { Group A } \\
\text { (n = 50) }\end{array}$ & $\begin{array}{l}\text { Group B } \\
\text { (n= 38) }\end{array}$ & p Value \\
\hline IVH & $19(38)$ & $24(63)$ & 0.02 \\
Severe IVH & $6(12)$ & $21(55)$ & 0.0001 \\
PVL & $2(4)$ & $3(8)$ & 0.64 \\
Survival day 28 & $44(88)$ & $26(68)$ & 0.077 \\
$\begin{array}{l}\text { Death before day 28 or } \\
\text { severe IVH }\end{array}$ & $8(16)$ & $24(63)$ & 0.0001 \\
BPD (FIO $>0.21$ at 36 weeks & $13(28)$ & $9(35)$ & 0.79 \\
gestation) & & & \\
\hline
\end{tabular}

Values in parentheses are percentages. Study population divided into two groups according to serum IL6 concentration at 12 hours of postnatal age: $A, \leqslant 100 \mathrm{pg} / \mathrm{ml} ; B,>100 \mathrm{pg} / \mathrm{ml}$.

IVH, Intraventricular haemorrhage; PVL, periventricular leucomalacia; $\mathrm{BPD}$, bronchopulmonary dysplasia.

Referring to the development of severe IVH in the study population $(27 / 88 ; 30 \%$; table 4$)$, we found a correlation with the variables gestational age $(\mathrm{p}=0.014)$, IL6 $>100 \mathrm{pg} / \mathrm{ml}$ $(p=0.0001)$, catecholamine treatment $(p=0.0001)$, and leucocyte count $(\mathrm{p}=0.037)$.

To determine the influence of inflammation on the development and extent of IVH, stepwise multivariate logistic regression models were applied separately for $(a)$ all patients with IVH (table 3 ) and ( $b$ ) patients with severe IVH (table 4 ). Variables included in the stepwise regression were gestational age, birth weight, antenatal steroid exposure, leucocyte count, $\mathrm{C}$ reactive protein $>5 \mathrm{mg} / \mathrm{l}$, cord blood $\mathrm{pH}$, catecholamine treatment, and serum IL6 concentration $>100 \mathrm{pg} / \mathrm{ml}$ at 12 hours of postnatal age. In the first regression model, gestational age (odds ratio (OR) 0.92, 95\% confidence interval (CI) 0.86 to 0.98 ) and catecholamine treatment (OR 3.6, 95\% CI 1.15 to 11.3 ) maintained independent variables associated with the development of IVH.

The second regression model confirmed the independent association of IL6 level $>100 \mathrm{mg} / \mathrm{dl}$ and catecholamine treatment with grade 3 IVH or IVH with periventricular white matter disease (OR 8.94, 95\% CI 3.1 to 25.7 ; OR $6.25,95 \%$ CI 2.04 to 19.1). The other confounding variables were excluded from the regression model.

\section{DISCUSSION}

The results of this clinical study emphasise the relevance of inflammatory processes in the pathogenesis of IVH in extremely premature infants. Infection of the fetomaternal unit increases the risk of preterm delivery and adverse neonatal outcome. ${ }^{5} 81428$ There is evidence that inflammatory umbilical cord lesions, elevated amniotic fluid, and cord blood IL6 levels are associated with increased neonatal morbidity. ${ }^{5} 681329$ IVH and PVL in preterm infants in early postnatal magnetic resonance imaging are apparently related to intrauterine $\mathrm{T}$ cell activation and increased proinflammatory activity. ${ }^{30}$ Studies on human cerebral microvascular endothelial cells indicate that these are capable of upregulating inflammatory endothelial mediators in response to proinflammatory cytokines or ischaemia. ${ }^{16}$ The upregulated expression of adhesion molecules in the endothelial cells, mediating neutrophil rolling and attachment, is the first step of tissue damage. Consecutive pathophysiological steps are vasoparalysis $^{16}$ and activation of microglial cytokine expression. ${ }^{31-35}$

There are thought to be many causes of IVH in premature infants. $^{10}{ }^{1136-38}$ Its incidence is independently related to gestational age and perinatal morbidity. ${ }^{10} 38$ Haemodynamic disturbances are known to be related to cerebral morbidity in preterm infants. ${ }^{10}{ }^{26}$ Recently, a study of infants of less than 
Table 3 Variables predicting intraventricular haemorrhage (IVH) in the study population (multivariate logistic regression model)

\begin{tabular}{|c|c|c|c|c|}
\hline \multirow[b]{2}{*}{ Variable } & \multirow{2}{*}{$\frac{\text { Unifactorial }\left(\chi^{2} \text { test }\right)}{p \text { Value }}$} & \multicolumn{3}{|c|}{ Multifactorial (stepwise logistic regression) } \\
\hline & & Odds ratio & $95 \% \mathrm{Cl}$ & $\mathrm{p}$ Value \\
\hline $\begin{array}{l}\text { Gestational age* } \\
\text { Birth weightt }\end{array}$ & $\begin{array}{l}0.003 \\
0.17\end{array}$ & 0.92 & 0.86 to 0.98 & 0.05 \\
\hline Antenatal steroid exposure $†$ & 0.66 & & & \\
\hline Leucocyłe count $(/ \mu l) \dagger$ & 0.52 & & & \\
\hline$C$ reactive protein $>5 \mathrm{mg} / \mathrm{l} \dagger$ & 0.78 & & & \\
\hline Cord blood pH arterial † & 0.8 & & & \\
\hline Catecholamine treatment ${ }^{\star}$ & 0.002 & 3.6 & 1.15 to 11.3 & 0.028 \\
\hline IL6 $>100 \mathrm{pg} / \mathrm{ml} \dagger$ & 0.034 & & & NS \\
\hline
\end{tabular}

Bold indicates significance.

*Variables included in first and second step of regression model.

†Variables excluded at first step of regression model. IL, Interleukin.

30 weeks gestation may show a correlation of fetal inflammatory response syndrome (chorioamnionitis, raised proinflammatory cord blood cytokines) with reduction of systemic blood pressure, right ventricular cardiac output, and increased incidence of severe IVH. ${ }^{39}$ As in the model of cerebral ischaemia-reperfusion injury by Suzuki et $a l^{35}$ systemic and local haemodynamic changes and cerebral endothelial damage may contribute to the inflammatory response as postulated in our primary hypothesis.

The study population was defined by gestational age, and not by birth weight, to exclude small for gestational age infants who account for about $20 \%$ of our patients with birth weight less than $1000 \mathrm{~g}$.

The CRIB score was determined from all study infants to assess the severity of clinical conditions in the first 12 hours of life (fig 1). The median CRIB score did not differ in the two study groups. It is a valid index of initial neonatal risk, predicting neonatal morbidity and mortality even in extremely low birthweight infants as shown by other studies. ${ }^{24} 25$ Statistical analysis of the perinatal data for the two study groups showed no difference in factors known to contribute to the increased risk of neonatal morbidity (antenatal steroids, gestational age, sex, patent ductus arteriosus, mechanical ventilation). Therefore we assume that the elevated serum IL6 concentrations measured at 12 hours of

Table 4 Variables predicting severe intraventricular haemorrhage (IVH) in the study population (multivariate logistic regression model)

\begin{tabular}{|c|c|c|c|c|}
\hline \multirow[b]{2}{*}{ Variable } & \multirow{2}{*}{$\begin{array}{l}\begin{array}{l}\text { Unifactorial } \\
\left(\chi^{2} \text { test }\right)\end{array} \\
\text { p Value }\end{array}$} & \multicolumn{3}{|c|}{$\begin{array}{l}\text { Multifactorial (stepwise logistic } \\
\text { regression) }\end{array}$} \\
\hline & & $\begin{array}{l}\text { Odds } \\
\text { ratio }\end{array}$ & $95 \% \mathrm{Cl}$ & p Value \\
\hline Gestational age $†$ & 0.014 & & & \\
\hline $\begin{array}{l}\text { Birth weight† } \\
\text { Antenatal steroid }\end{array}$ & $\begin{array}{l}0.73 \\
0.9\end{array}$ & & & \\
\hline & 0.037 & & & \\
\hline $\begin{array}{l}(/ \mu l) \dagger \\
C \text { reactive protein }\end{array}$ & 0.49 & & & \\
\hline $\begin{array}{l}>5 \mathrm{mg} / \mathrm{l} \dagger \\
\text { Cord blood pH }\end{array}$ & 0.39 & & & \\
\hline $\begin{array}{l}\text { arterialt } \\
\text { Catecholamine } \\
\text { treatment }^{*}\end{array}$ & & 6.25 & $2.04-19.1$ & 0.0001 \\
\hline $\begin{array}{l}\text { treatment* } \\
\text { IL6 > } 100 \mathrm{pg} / \mathrm{ml}\end{array}$ & 0.0001 & 8.94 & $3.1-25.7$ & 0.0001 \\
\hline \multicolumn{5}{|c|}{$\begin{array}{l}\text { Bold indicates significance. } \\
\text { *Variables included at first and second step of regression model. } \\
\text { tVariables excluded at first step of regression model. } \\
\text { IL, Interleukin. }\end{array}$} \\
\hline
\end{tabular}

life do not indicate a secondary serum response to perinatal stimuli or represent, irrespective of neonatal inflammation, a sicker infant per se. Owing to the retrospective design of the study, placental histology was not available for all of the study infants to correlate inflammation of the fetomaternal unit with neonatal IL6 serum concentrations and neonatal morbidity.

Studies on the evaluation of IL6 for early diagnosis of neonatal infection indicate that cut off values of $80-100 \mathrm{pg} / \mathrm{ml}$ are ideal, detecting early neonatal infection with a high degree of sensitivity and specificity..$^{21}{ }^{40}$ We chose a cut off value within that range, to exclude other confounding perinatal variables (delivery mode, period of delivery) that might have influenced serum IL6 concentration. ${ }^{41}$

The incidence of IVH found in the study population (43/88) corresponds to other observations..$^{9-11}$ Almost a third (27/88) of the patients in our study developed grade 3 IVH or IVH with apparent haemorrhagic infarction. We did not differentiate between IVH and PVL for the statistical analysis. All cases of PVL in our study population were multicystic PVL. ${ }^{42}$ It was coincidental with severe IVH found in five patients (one grade $3 \mathrm{IVH}$, four IVH + periventricular haemorrhagic infarction). It has been shown that the extent of white matter lesions is coherent with the severity of IVH. ${ }^{43}$

The first stepwise logistic regression (variables associated with IVH) confirmed that gestational age and catecholamine treatment were independently associated with the development of IVH. In the second regression model (variables associated with severe IVH), IL6 concentration $>100 \mathrm{pg} / \mathrm{ml}$ and catecholamine treatment correlated with severe IVH.

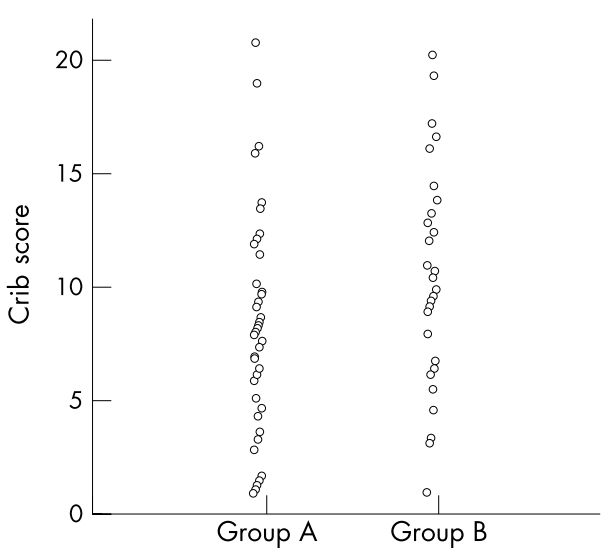

Figure 1 Distribution of CRIB score in group A (IL6 $\leqslant 100 \mathrm{pg} / \mathrm{ml}) v$ group B (IL6 > $100 \mathrm{pg} / \mathrm{ml})(\mathrm{n}=88)(\mathrm{p}=0.063)$. The graphic is jittered $(5 \%)$ to figure overlapping data. 
Our data indicate that inflammatory mechanisms may not be separable from other variables that predict cerebral morbidity in a study population of less than 28 weeks gestation. Early neonatal systemic inflammation and haemodynamic disturbances seem to be linked pathophysiological mechanisms which determine the extent of cerebral morbidity in extremely premature infants. Measurement of serum IL6 concentrations provides important clinical

information on early anti-inflammatory processes, before histopathology can confirm fetal involvement in amniotic infection. ${ }^{24}$

\section{Authors' affiliations}

A Heep, D Behrendt, P Nitsch, P Bartmann, J Dembinski, Department of Neonatology, Informatics and Epidemiology, University of Bonn, Germany

R Fimmers, Institute for Medical Biometry, Informatics and Epidemiology, University of Bonn, Germany

\section{REFERENCES}

1 Winkler M, Rath W, Fischer DC. Regulation of interleukin-8 synthesis in human lower uterin segment fibroblasts by cytokines and growth factors. Obstet Gynecol 2000;95:584-8.

2 DeFelice C, Toti P, Laurini RN, et al. Early neonatal brain injury in histologic chorioamnionitis. J Pediatr 2001;138:101-3

3 Yoon BH, Romero R, Park JS, et al. The relationship among inflammatory lesions of the umbilical cord (funisitis), umbilical cord plasma interleukin-6 concentration, amniotic fluid infection, and neonatal sepsis. Am J Obstet Gynecol 2000;183:1124-9.

4 Groneck P, Tauscher M, Stiller S, et al. Association of chorioamnionitis, increased levels of cord blood cytokines and intracerebral hemorrhage in preterm neonates [abstract]. Pediatr Res 1999:45:910(A).

5 Gomez R, Romero R, Ghezzi F, et al. The fetal inflammatory response syndrome. Am J Obstet Gynecol 1998;179:194-202.

6 Dammann O, Leviton A. Maternal intrauterin infection, cytokines, and brain damage in the preterm newborn. Pediatr Res 1997:42:1-8.

7 Weeks JW, Reynolds L, Taylor D, et al. Umbilical cord blood interleukin-6 levels and neonatal morbidity. Obstet Gynecol 1997;90:815-18.

8 Yoon BH, Jun JK, Romero R, et al. Amniotic fluid inflammatory cytokines (interleukin-6, interleukin-1 $\beta$, and tumor necrosis factor- $\alpha$ ), neonatal brain white matter lesions, and cerebral palsy. Am J Obstet Gynecol 1997; 177:19-26.

9 Synnes AR, Chien LY, Peliowski A, et al. Variations in intraventricular hemorrhage incidence rates among Canadian neonatal intensive care units. J Pediatr 2001;138:525-31.

10 Volpe JJ. Intracranial hemorrhage: germinal matrix-intraventricular hemorrhage of the premature infant. In: Neurology of the newborn. Philadelphia: WB Saunders, 2001:428-93.

11 Papile LA, Burstein J, Burstein R, et al. Incidence and evolution of subependymal and intraventricular hemorrhage: a study of infants with birth weights less than 1,500 gm. J Pediatr 1978;92:529-34.

12 Heep A, Dembinski J, Kau N, et al. Neonatal inflammatory response: early serum interleukin-6 predicts cerebral morbidity in premature infants $<28$ weeks of gestational age [abstract]. Biol Neonate $2001 ; 80: 321$ (A).

13 Duggan PJ, Edwards AD. Placental inflammation and brain injury in preterm infants. Dev Med Child Neurol 2001;86:16-17.

14 Yoon BH, Kim CJ, Romero R, et al. Experimentally induced intrauterine infection causes fetal brain white matter lesions in rabbits. Am J Obstet Gynecol 1997;177:797-802.

15 Yoon BH, Romero R, Kim CJ, et al. High expression of tumor necrosis factor- $\alpha$ and interleukin- 6 in periventricular leukomalacia. Am J Obstet Gynecol 1997; 177:406-11.

16 Stanimirovic D, Satoh K. Inflammatory mediators of cerebral endothelium. Brain Pathol 2000;10:113-26.

17 Maskin B, Gamella D, Solari L, et al. Early release of the antiinflammatory cytokine IL-10 in traumatic brain injury. Medicina 2001;61:573-6.
18 Sävman K, Blennow M, Gustafson K, et al Cytokine response in the cerebrospinal fluid after birth asphyxia. Pediatr Res 1998;43:746-51.

19 Gatti S, Bartfai T. Induction of tumor necrosis factor- $\alpha$ mRNA in the brain after peripheral endotoxin treatment: comparison with interleukin-1 family and interleukin-6. Brain Res 1993;624:291-4.

20 Schultz C, Rott C, Temming P, et al. Enhanced interleukin-6 and interleukin-8 synthesis in term and preterm infants. Pediatr Res 2002;51:317-22.

21 Krueger M, Nauck MS, Sang S, et al. Cord blood levels of interleukin-6 and interleukin- 8 for the immediate diagnosis of early-onset infection in premature infants. Biol Neonate 2001;80:118-23.

22 De Vries HE, Blom-Roosemalen MC, van Oosten $M$, et al. The influence of cytokines on the integrity of the blood-brain barrier in vitro. $J$ Neuroimmunol 1996;64:37-43.

23 Mark K, Miller D. Increased permeability of primary cultured brain microvessel endothelial cell monolayers following TNF- $\alpha$ exposure. Life Sci 1999;64:1941-53.

24 Buhrer C, Grimmer I, Metze B, et al. The CRIB (Clinical Risk Index for Babies) score and neurodevelopmental impairment at one year corrected age in very low birth weight infants. Intensive Care Med 2000;26:325-9.

25 Lago P, Freato F, Bettiol T, et al. Is the CRIB score (Clinical Risk Index for Babies) a valid tool in predicting neurodevelopmental outcome in extremely low birth weight infants? Biol Neonate 1999;76:220-7.

26 Bada $\mathrm{H}$, Korones S, Perry E, et al. Mean arterial blood pressure changes in premature infants and those at risk for intraventricular hemorrhage. J Pediatr 1990;117:607-14.

27 Murphy BP, Inder TE, V Rooks, et al. Posthaemorrhagic ventricular dilatation in the premature infant: natural history and predictors of outcome. Arch Dis Child Fetal Neonatal Ed 2002;87:F37-F41.

28 Davies JK, Shikes RH, Sze Cl, et al. Histologic inflammation in the maternal and fetal compartments in a rabbit model of acute intra-amniotic infection. Am J Obstet Gynecol 2000;183:1088-93.

29 Cai Z, Pan ZL, Pang Y, et al. Cytokine induction in fetal rat brains and brain injury in neonatal rats after maternal lipopolysaccharide administration. Pediatr Res 2000;47:64-8.

30 Duggan PJ, Maalouf EF, Watts TL, et al. Intrauterin T-cell activation and increased proinflammatory cytokine concentrations in preterm infants with cerebral lesions. Lancet 2001;358:1699-700.

31 Acarin L, Gonzales B, Castellano B. Neuronal astroglial and microglial cytokine expression after an excitotoxic lesion in the immature rat brain. Eur J Neurosci 2000;12:3505-20.

32 Eklind S, Mallard C, Leverin AL, et al. Bacterial endotoxin sensitizes the immature brain to hypoxic-ischaemic injury. Eur J Neurosci 2001;13:1101-6.

33 Van Dam AM, Baver J, Tilders FJH, et al. Endotoxin-induced appearance of immunoreactive interleukin-1 $\alpha$ in ramified microglia in rat brain: a light and electron microscopic study. Neuroscience 1995;65:815-26.

34 Raivich G, Jones LL, Werner A et al. Molecular signals for glial activation: pro-and anti-inflammatory cytokines in the injured brain. Acta Neurochir Suppl 1999;73:21-30.

35 Suzuki S, Tanaka K, Nogawa S, et al. Temporal profile and cellular localization of interleukin-6 protein after focal cerebral ischemia in rats. J Cereb Blood Flow Metab 1999; 19:1256-62.

36 Volpe JJ. Intraventricular hemorrhage and brain injury in the premature infant: diagnosis, prognosis and prevention. Clin Perinatol 1989;16:387-41 1.

37 duPlessis AJ. Posthemorrhagic hydrocephalus and brain injury in the preterm infant: dilemmas in diagnosis and management. Semin Paediatr Neurol 1998;5:161-79.

38 Tortorolo G, Luciano R, Papacci P, et al. Intraventricular hemorrhage: past present and future, focusing on classification, pathogenesis and prevention. Child's Nerv Syst 1999:15:652-61.

39 Yanowitz TD, Jordan JA, Gilmour C, et al. Hemodynamic disturbances in premature infants born after chorioamnionitis: association with cord blood cytokine concentrations. Pediatr Res 2002;51:310-16.

40 Messer J, Eyer D, Donato L, et al. Evaluation of interleukin-6 and soluble receptors of tumor necrosis factor for early diagnosis of neonatal infection. J Pediatr 1996;129:574-80.

41 Protonotariou E, Malamitsi-Puchner A, Giannaki G, et al. Patterns of inflammatory cytokine serum concentrations during perinatal period. Early Hum Dev 1999.56:31-8.

42 Paneth N. Classifying brain damage in preterm infants. J Pediatr 1999; 134:527-9.

43 Kuban K, Sanocka U, Leviton A, et al. White matter disordes of prematurity: association with intraventricular hemorrhage and ventriculomegaly. J Pediatr 1999; 134:539-46. 